\title{
Mechanisms of Action of Apple Thinning Chemicals
}

\author{
Frank G. Dennis, Jr. ${ }^{1}$ \\ Department of Horticulture, Michigan State University, East Lansing, MI 48824-1325
}

Flower and fruit thinning, whether mechanical or chemical, prevent the development of some fruits, allowing the remainder to become larger and more marketable. Chemicals used for thinning either prevent fruit set or increase the proportion of fruits that fall in the "June drop"; some, however, are effective even after this drop. The mechanisms involved in blossom thinning are straightforward; pollination, fertilization, or both, are prevented, or some of the flowers are injured, inducing their abscission. The mechanisms involved in fruit thinning are more complex; physiologists continue to debate the relative importance of effects of applied chemicals on phloem transport, endogenous hormone content/biosynthesis, seed development, and other physiological processes. The effects of ethephon in thinning have led to the suggestion that the response to applied hormones may be mediated by their effects in stimulating ethylene biosynthesis. In this paper, I will review the evidence for the mechanisms of action of thinning agents for apple (Malus $\times$ domestica Borkh.).

This subject has been reviewed in many previous publications (e.g., Bangerth, 2000; Batjer and Billingsley, 1964; Dennis, 1986 1995, 2000; Edgerton, 1973a, 1973b; Tromp and Wertheim, 1980; Williams, 1979). At least eight such mechanisms have been proposed to explain the thinning action of applied chemicals (Table 1); the mode of action is probably not identical for all chemicals.

\section{SITE OF ACTION}

Before considering these mechanisms, some discussion of the site(s) of action is in order, i.e., whether the chemical is more effective when applied to the leaf or to the fruit (seeds) alone. The data available are summarized in Table 2. Schneider and Lasheen (1973) applied naphthaleneacetic acid (NAA) to the leaves alone or to fruits and leaves of 'Golden Delicious' and 'Stayman'. Both methods were equally effective. In a study to determine the importance of seeds in fruit retention, Abbott (1958) applied NAA to the cut surface (and seeds) of young 'Crawley Beauty' apple fruits; replication was limited, but the treatment appeared to promote abscission during the first 2 weeks after petal fall, inhibit it for the next 3 weeks, and have no effect thereafter. Benzyladenine (BA) is more effective in thinning when applied to the leaf, rather than to the fruit (Greene et al., 1992); in contrast, the effect of the chemical in stimulating fruit growth, aside from any thinning effect, is greater when applied to the fruit. Williams and Batjer (1964) applied carbaryl to spur leaves or to fruits; fruit drop (average for three orchards) was increased from 17\% (control) to $30 \%$ and $53 \%$ for leaf and fruit application, respectively. They concluded that application to the fruit was required for maximum effect. Knight (1983), in a similar experiment, applied carbaryl to the rosette leaves of the spur, to the bourse leaves, to the pedicel of the fruitlet, or to the fruit itself. In contrast with Williams and Batjers's observations, only treatment of the rosette leaves was ineffective. Byers et al. (1990a) also treated leaves only, fruits only, or both leaves and fruits with carbaryl. On well-exposed spurs, abscission occurred only when the fruits were treated, supporting the conclusions of Williams and Batjer; however, all treatments were equally effective when spurs were shaded for $4 \mathrm{~d}$ beginning on the day of treatment. Byers et al. (1985) demonstrated that terbacil (3-tert-butyl-5-chloro-6methyluracil), a herbicide that inhibits photosynthesis, was effective when applied to the leaf, but not when applied to the fruit. No reports of effects of ethephon on leaves vs. fruits are known. In summary, NAA appears to be equally effective on leaves and fruits, BA is more effective on the leaf, and carbaryl appears to be more effective on the fruit, provided that photosynthates are not limiting.

Received for publication 7 Feb. 1999. Accepted for publication 29 Sept. 2001 'E-mail address: fgdennis@msu.edu
Table 1. Mechanisms proposed to explain how applied chemicals thin apple fruits.

1. Abort seeds or inhibit their development

2. Delay abscission, thereby increasing competition among fruits and stimulating fruit drop.

3. Block transport of nutrients to fruit

4. Reduce sink strength of fruit

5. Reduce auxin synthesis by the seed

6. Reduce auxin transport from fruit

7. Stimulate ethylene biosynthesis

8. Inhibit photosynthesis

\section{SEED ABORTION/INHIBITION OF SEED DEVELOPMENT}

Naphthalene acetic acid was the first chemical to be used extensively for thinning, hence more work has been done with NAA than with any other chemical. Luckwill (1953) observed that fruits from NAA-treated trees contained fewer seeds than did control fruits, and proposed that NAA induced seed abortion. This presumably reduced the ability of the fruits to compete for nutrients, leading to abscission of those with the fewest seeds. Murneek and Teubner (1955) reported that growth of the embryo was inhibited following treatment of 'Wealthy' fruits with NAA, lending further support to this hypothesis. However, the thinning action of NAA is not always associated with embryo abortion. 'Delicious' fruits tend to have fewer seeds following application of NAA or carbaryl (Batjer and Thomson, 1961), but NAA can thin several other cultivars, including McIntosh, Golden Delicious, Winesap, and Jonathan, without affecting seed number (Batjer and Thomson, 1961; Marsh et al., 1960). Even in 'Delicious', seed number may not be affected (Batjer and Billingsley, 1964). If NAA thins by inducing seed abortion, direct application to the seeds should have the same effect. However, the data of Abbott (1958) cited above suggest that this is not always the case. The fact that seedless fruits can be thinned by NAA (Dennis, 1970) casts further doubt on the role of seed abortion as the mechanism of action. If seeds are involved, one might expect to find NAA in the seed following application to the leaves. Luckwill and Lloyd-Jones (1962) applied carboxyl-labeled ${ }^{14} \mathrm{C}-\mathrm{NAA}$ to the leaves of 'Millers Seedling'. Only $0.2 \%$ of the ${ }^{14} \mathrm{C}$ was recovered from the seeds, and none of this was NAA. In contrast, Donoho et al. (1961) found ${ }^{14} \mathrm{C}$ in the fruit within $1 \mathrm{~h}$, and in the seeds within $4 \mathrm{~d}$, after application of ring-labeled NAA to the leaf.

\section{DELAY OF ABSCISSION, INCREASING COMPETITION FOR NUTRIENTS}

Struckmeyer and Roberts (1950) observed that fruit abscission was delayed following application of NAA, although more fruits eventually abscised from the treated trees than from control trees. They proposed

Table 2. Evidence for site of action of fruit thinning agents

\begin{tabular}{|c|c|c|}
\hline Compound & Site & Reference \\
\hline \multirow[t]{2}{*}{ NAA } & Leaf $=$ leaf + fruit & Schneider and Lasheen, 1973 \\
\hline & $\begin{array}{l}\text { Seed alone } \\
\quad \mathrm{PF}+3-5 \mathrm{wk}-\text { yes } \\
\mathrm{PF}+1,2,6-10 \mathrm{wk}-\text { no }\end{array}$ & Abbott, 1958 \\
\hline \multirow{2}{*}{$\begin{array}{l}\text { BA (thinning) } \\
\text { (fruit size) }\end{array}$} & Leaf $>$ fruit & Greene et al., 1992 \\
\hline & Leaf $<<$ fruit & \\
\hline \multirow[t]{3}{*}{ Carbaryl } & Leaf $<$ fruit & Williams and Batjer, 1964 \\
\hline & $\begin{array}{l}\text { Leaf }<\text { fruit in sun } \\
\text { Leaf }=\text { fruit in shade }\end{array}$ & Byers et al., 1990a \\
\hline & $\begin{array}{l}\text { Spur leaf }<\text { bourse leaf }= \\
\quad=\text { pedicel }=\text { fruit }\end{array}$ & Knight, 1983 \\
\hline Terbacil & Leaf $>$ fruit & Byers et al., 1985 \\
\hline
\end{tabular}


that NAA delayed abscission, resulting in greater competition for nutrients, and that this eventually resulted in a higher percentage abscission than in control trees. Hartman and Howlett (1962) provided supporting data based upon their work with 'Golden Delicious'. However, Batjer and Billingsley (1964), using both NAA and carbaryl on 'Golden Delicious', could find no support for this hypothesis. Several investigators have observed an inhibition of fruit growth soon after NAA application (Southwick et al., 1962; Teubner and Murneek, 1955); this should reduce rather than increase competition for nutrients.

\section{BLOCKAGE OF TRANSPORT OF NUTRIENTS FROM LEAF TO FRUIT ( = REDUCTION OF SINK STRENGTH)}

Relatively few data are available to support/refute this hypothesis. Schneider and Lasheen (1973) observed that, although carbaryl had little effect, application of NAA to 'Golden Delicious' lowered the content of reducing sugars in the fruit. Subsequently, Schneider (1975) reported that application of NAA reduced the transport of sugars from leaf to fruit in 'Golden Delicious' and 'Stayman'. However, NAA did not affect movement of IAA or sucrose in the excised pedicel in either direction (Schneider, 1973). From these data Schneider (1975) concluded that NAA induced sinks in vegetative tissues that reduced the amount of metabolites reaching the fruit. Williams and Batjer (1964) observed that carbaryl was transported only slowly from the leaf to the fruit. From this fact they inferred that carbaryl interfered with the movement of "vital chemicals" from either spur to fruit or seed to abcission zone; however, they did not measure the transport of carbohydrates. Knight (1983), on the basis of his studies with carbaryl (see above), suggested that the chemical might enhance sink activity in the bourse shoot, thus reducing export of photosynthates to the fruit. However, this hypothesis does not explain why it is effective when applied to the fruit alone. Yuan and Greene (2000) reported that application of BA to the fruit stimulated import of ${ }^{14} \mathrm{C}$-sorbitol from the leaf, whereas similar treatment of the leaf did not affect movement to the fruit. Thus BA does not appear to block transport. (See section on photosynthesis below.) No studies are known as to the effects of ethephon on transport in relation to thinning effect.

\section{AUXIN SYNTHESIS/TRANSPORT}

Crowe (1965) and Ebert and Bangerth $(1981,1982)$ presented data indicating that NAA reduced auxin synthesis and/or transport from the fruit to the abscission zone. Crowe (1965), using the Avena mesocotyl assay, reported that the amount of auxin in diffusates from pedicels of 'Golden Delicious' fruitlets was reduced within $24 \mathrm{~h}$ of NAA application, and remained low for more than 2 weeks. Ebert and Bangerth $(1981,1982)$ measured both extractable and diffusible auxin in fruits of three cultivars following application of naphthaleneacetamide (NAD), carbaryl, and ethephon. The most consistent effect was a reduction in the amount of diffusible auxin recovered. However, Schneider (1973) found no effect of either carbaryl or NAA on transport of either ${ }^{14} \mathrm{C}$-sucrose or IAA through detached 'Golden Delicious' pedicels.

\section{STIMULATION OF ETHYLENE BIOSYNTHESIS}

Both ethylene and ethephon (2-chloroethylphosphonic acid), which breaks down in the tissue to release ethylene, are effective in promoting fruit abscission, both before and during "June drop" and at harvest. Thus, a logical hypothesis is that fruit thinning agents stimulate ethylene synthesis in the fruit, pedicel tissue, or both, and that ethylene is responsible for abscission. Murneek (1954) appears to have been the first to propose a role for ethylene in the thinning action of NAA. On the basis of limited evidence, he proposed that NAA uncouples oxidative phosphorylation, leading to: 1) a reduction in hormone content of the endosperm, 2) reduced fruit growth, 3) inhibition of embryo growth, and 4) an increase in ethylene production. However, Teubner and Murneek (1955) were unable to find a correlation between ethylene production following NAA application and abscission. Schneider (1974) tested this hypothesis, using NAA, NAD, and carbaryl, but concluded that response was not dependent upon ethylene production.
Chiba and Kubota (1979) also measured ethylene evolution from fruitlets of three cultivars following treatment with carbaryl. Thinning response was greater in 'Delicious' than in 'Jonathan', with little or no response in 'Ralls'. The treatment stimulated ethylene evolution in 'Delicious', but not in the other cultivars, again casting doubt on the hypothesis. However, both Walsh et al., (1979) and Williams (1981) reported a correlation between ethylene evolution and abscission, both of which were stimulated by both NAA and ethephon. Based on the data of Walsh et al. (1979), I calculated $R^{2}$ values for the regression of fruit remaining vs. the rate of evolution of ethylene; this was significant for 'Northern Spy', but not for 'Golden Delicious' (Fig. 1). Omission of the values for ethephon treatments would have increased the value of $R^{2}$, but this would have left only one degree of freedom; thus too few data are available for valid evaluation. Williams (1981) observed that aminoethoxyvinyl glycine (AVG), which inhibits ethylene synthesis, counteracted the effects of NAA or NAA plus carbaryl on both thinning and ethylene evolution, whereas it was ineffective in preventing thinning by ethephon (Table 3). Analysis of Williams's data again indicates nonsignificant $R^{2}$ values, but, again, too few data are available. Ebert and Bangerth $(1981,1982)$ measured internal ethylene concentrations in fruitlets of three cultivars following treatment with NAA, NAD, and ethephon. Only when ethephon was used was the ethylene content increased dramatically; NAA had little effect on ethylene production, carbaryl had none, and thinning response did not parallel fruit ethylene content. Greene et al. (1992) also reported a poor correlation between ethylene evolution from leaves and fruits and thinning response in Rogers 'McIntosh' fruits following treatment with NAA or BA. Rahemi (1981) measured ethylene evolution from small (high abscission potential) vs. large (low potential) apple fruits during the "June" drop. Although no thinning agents were applied, ethylene production was similar in both populations when plotted against fruit weight, rather than date of sampling. This suggests that ethylene is not the primary factor controlling "June" drop. Thus the role of ethylene in the mechanism of action of NAA remains controversial.

\section{INHIBITION OF PHOTOSYNTHESIS}

Both shading (Byers et al. 1985; Schneider, 1977) and application of chemicals that inhibit photosynthesis, such as terbacil (Byers, et al., 1985, 1990b), stimulate apple fruitlet abscission, suggesting that thinning chemicals may interfere with photosynthesis, leading to a defi-

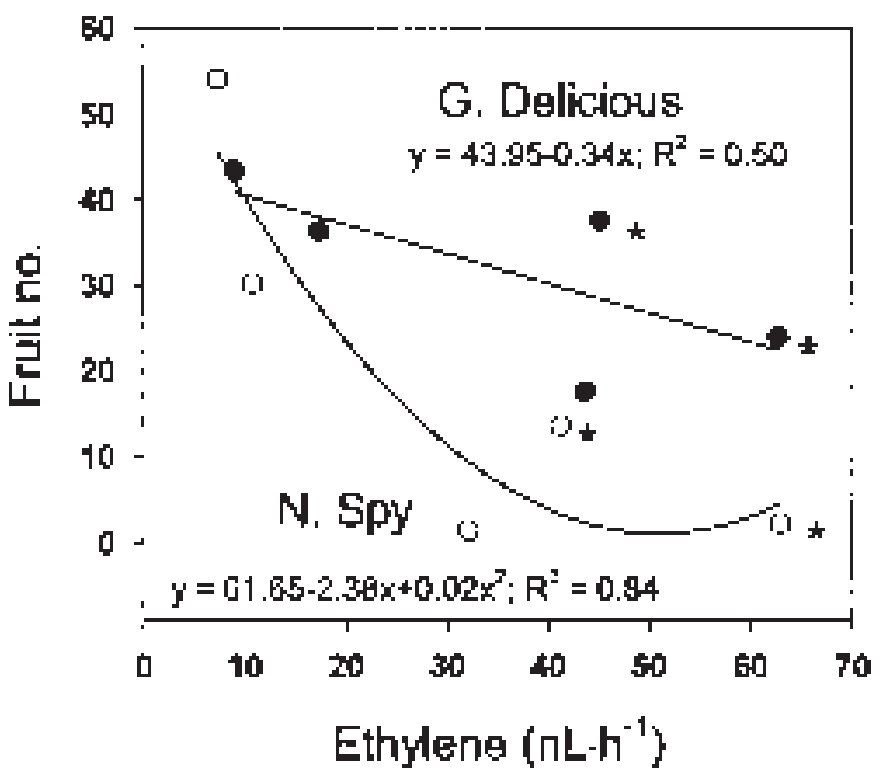

Fig. 1. Regression of (y) number of fruit of two apple cultivars persisting $14 \mathrm{~d}$ after petal fall following application of thinning chemicals (water control; $50 \mathrm{mg} \cdot \mathrm{L}^{-1} \mathrm{NAD} ; 15 \mathrm{mg} \cdot \mathrm{L}^{-1} \mathrm{NAA}$; and $100 \mathrm{mg} \cdot \mathrm{L}^{-1}$ ethephon) on (x) rate of ethylene evolution (nL $\cdot \mathrm{h}^{-1}$ per spur) by fruiting spurs $1 \mathrm{~d}$ after treatment (based upon data of Walsh et al., 1979). Asterisks indicate data for ethephon treatments. $R^{2}$ for 'N. Spy' significant at $P<0.05 ; R^{2}$ for 'G. Delicious' NS. 
Table 3. Effects of naphthaleneacetic acid (NAA), carbaryl, and aminoethoxyvinylglycine $(A V G)$ and their interactions on fruit set and ethylene production of 'Spur Delicious' apple. ${ }^{\mathrm{z}}$

\begin{tabular}{|c|c|c|c|c|}
\hline \multirow{2}{*}{$\begin{array}{l}\text { Thinning } \\
\text { chemical }\end{array}$} & \multirow{2}{*}{$\begin{array}{c}\text { AVG } \\
\left(400 \mathrm{mg} \cdot \mathrm{L}^{-1}\right)\end{array}$} & \multirow{2}{*}{$\begin{array}{l}\text { Fruits per } \\
100 \text { clusters }\end{array}$} & \multicolumn{2}{|c|}{$\begin{array}{c}\text { Ethylene evolution } \\
\left(\mathrm{nL} \cdot \mathrm{g}^{-1} \cdot \mathrm{h}^{-1} \text { after } 24 \mathrm{~h}\right)\end{array}$} \\
\hline & & & Leaf & Fruit \\
\hline \multicolumn{5}{|c|}{1980} \\
\hline \multirow[t]{2}{*}{ None } & - & 80 & 3.0 & 4.4 \\
\hline & + & 116 & 1.5 & 1.8 \\
\hline \multirow[t]{2}{*}{ NAA $(10)^{y}$} & - & 49 & 21.9 & 6.7 \\
\hline & + & 80 & 3.8 & 1.5 \\
\hline \multirow[t]{3}{*}{ Carbaryl (750) } & - & 68 & 1.8 & 5.6 \\
\hline & + & 94 & 2.0 & 3.0 \\
\hline & & 1981 & & \\
\hline \multirow[t]{2}{*}{ None } & - & 70 & 1.4 & 0.6 \\
\hline & + & 90 & 1.0 & 0.3 \\
\hline \multirow{2}{*}{$\begin{array}{l}\text { NAA }(5) \text { plus } \\
\text { carbaryl }(600)\end{array}$} & - & 28 & 4.9 & 1.2 \\
\hline & + & 72 & 2.9 & 0.1 \\
\hline \multirow[t]{2}{*}{ Ethephon (450) } & - & 21 & 161.0 & 6.6 \\
\hline & + & 24 & 265.0 & 5.9 \\
\hline
\end{tabular}

${ }^{\text {zNAA }}$ and carbaryl treatments applied $14 \mathrm{~d}$ after bloom, AVG applied $3 \mathrm{~h}$ later. (Williams, 1981).

${ }^{\mathrm{y}}$ Numbers in parentheses are concentrations in $\mathrm{mg} \cdot \mathrm{L}^{-1}$.

ciency of carbohydrates. Schumacher et al. (1993) observed that NAD application reduced photosynthesis slightly in 'Golden Delicious' leaves, and Stopar et al. (1997) found that NAA application inhibited carbon assimilation by as much as $25 \%$ in 'Delicious' and 'Empire' leaves; some inhibition was evident for as long as 2 weeks. The treatments $\left(7.5\right.$ and $\left.15 \mathrm{mg} \cdot \mathrm{L}^{-1}\right)$ used by Stopar et al. (1997) were applied too late to affect fruitlet abscission. Stopar et al. (1997) found no effect of BA on photosynthesis; however, Yuan and Greene (2000) reported that net photosynthesis was reduced $10 \%$ to $15 \%$ following application of BA at 50 or $100 \mathrm{mg} \cdot \mathrm{L}^{-1}$. The treatment increased dark respiration at $30{ }^{\circ} \mathrm{C}$, but not at $20^{\circ} \mathrm{C}$, and the authors suggested that stimulation of dark respiration might reduce carbohydrate supply to the fruit, leading to its abscission. No studies are known in which the effects of carbaryl or ethephon on photosynthesis have been evaluated.

\section{CONCLUSIONS AND SUGGESTIONS FOR FURTHER RESEARCH}

Most thinning agents are effective only when applied prior to the period of "June drop", when fruitlet abscission is occurring spontaneously. Fruit abscission is not accompanied by leaf abscission, nor do thinning agents induce leaf abscission when applied at this time. These facts suggest that the chemicals only stimulate the process of natural abscission and fruit and leaf abscission are regulated by different processes, at least during this early period of fruit development. Various forms of stress (e.g., shading, drought, excessive fruit load) increase fruit drop, and chemical thinners may merely provide additional stress. However, this does not explain how such stress is induced.

Of the mechanisms discussed, direct effects on the seed (embryo abortion, reduction of auxin synthesis/transport) are unlikely given that: 1) thinning can occur without reducing seed number per fruit; 2) NAA can thin seedless fruits; and 3) direct application of NAA to the seed does not appear to result in abscission, and may in fact prevent it, depending upon timing. This last observation should be confirmed, as it is based upon the data of Abbott (1958), whose experiments were not designed to answer the questions posed here. A problem in such studies is the strong tendency of very young fruits to abscise when injured; a less drastic method of application might be injection of NAA into the locules, using a syringe.

Increased competition among fruitlets, caused by delayed abscission following treatment, is ruled out as a mechanism of thinning by data indicating that treated fruitlets often fall before, or no later than, control fruitlets. Blockage of phloem transport to the fruit and/or diversion of nutrients from the fruit (reduced sink strength) remain possibilities, but are not well-documented. The role of ethylene in thinning remains controversial, with evidence both for and against its participation in the thinning action of NAA. The action of carbaryl, on the other hand, appears to be independent of ethylene. While the photosynthetic inhibition hypothesis is an attractive one, given the effects of shading and photosynthetic inhibitors on fruit abscission, many gaps remain in the evidence. No effect of carbaryl has been reported, and the lowest active concentrations of NAA are unlikely to have major effects on assimilation rates. Therefore, no one hypothesis appears to fit all chemicals, given the differences in both their sites of action and their effects on ethylene evolution, transport, etc.

Research is needed to provide a better understanding of the mechanisms of action of chemical thinners. Cultivars differ considerably in their responses to such chemicals, yet few comparative studies have been made as to why they differ. The effects of ethephon and AVG in relation to the role of ethylene in thinning should be explored more fully, as rather high concentrations of both have been used in experiments to date. More extensive studies, with more concentrations of both chemicals, might reveal how good the correlation is between ethylene evolution and thinning. Similarly, the effects of the chemicals in inhibiting photosynthesis, perhaps in conjunction with shading experiments, should be investigated more systematically to determine how important this effect is in inducing abscission. The mechanism of action of carbaryl, especially, should be explored more fully, given that it has little effect on photosynthesis, ethylene evolution, etc. No research is known in which molecular techniques have been used; this field of study remains wide open.

A coordinated approach, as suggested by Wertheim (2000), is needed, and, given the importance of the subject and the numbers of persons engaged in thinning studies, should not be difficult to develop. A forum or working group, such as the former U.S. Dept. of Agriculture Western Regional Project WRCC-17 on flowering, fruit set and development, would be a logical focal point for such coordination. If cooperators establish clearly defined goals, and are committed to achieving them, much progress can be made toward providing answers to many of the questions being asked today.

\section{Literature Cited}

Abbott, D.L. 1958. The effects of seed removal on the growth of apple fruitlets. Annu. Rpt. Long Ashton Res. Sta. for 1958, p. 52-56.

Bangerth, F. 2000. Abscission and thinning of young fruit and their regulation by plant hormones and bioregulators. Plant Growth Regulat. 31:43-50.

Batjer, L.P. and H.D. Billingsley. 1964. Apple thinning with chemical sprays. Washington State Agr. Expt. Sta. Bul. 651.

Batjer, L.P. and B.J. Thomson. 1961. Effect of 1-naphthyl N-methylcarbamate (Sevin) on thinning apples. Proc. Amer. Soc. Hort. Sci. 77:1-8.

Byers, R.E., J.A. Barden, and D.H. Carbaugh. 1990a. Thinning of spur 'Delicious' apples by shade, terbacil, carbaryl, and ethephon. J. Amer. Soc. Hort. Sci. 115:9-13.

Byers, R.E., J.A. Barden, R.F. Polomski, R.W. Young, and D.H. Carbaugh 1990b. Apple thinning by photosynthetic inhibition. J. Amer. Soc. Hort. Sci. 115:14-19.

Byers, R.E., C.G. Lyons Jr., K.S. Yoder, J.A. Barden, and R.W. Young. 1985. Peach and apple thinning by shading and photosynthetic inhibition. J. Hort. Sci. 60:465-472.

Chiba, K. and K. Kubota. 1979. Fruit drop and ethylene evolution and the effects of 1-naphthyl N-methylcarbamate on them in apple fruitlets (In Japanese with English summary). Bul. Fruit Tree Res. Sta. -C - Marioka No. 6, p. 55-64.

Crowe, A.D. 1965. Effect of thinning sprays on metabolism of growth substances in the apple. Proc. Amer. Soc. Hort. Sci. 86:23-27.

Dennis, F.G., Jr. 1970. Effects of gibberellins and naphthalenacetic acid on fruit development in seedless apple clones. J. Amer. Soc. Hort. Sci 95:125-128

Dennis, F.G., Jr. 1986. Apple, p. 1-44. In: S.P. Monselise (ed.). Handbook of fruit set and development. CRC Press, Boca Raton, Fla.

Dennis, F.G., Jr. 1995. Thinning apples with Sevin. Proc. Michigan State Hort. Soc. 125:160-164.

Dennis, F.G., Jr. 2000. The history of fruit thinning. Plant Growth Regulat. 31:1-16.

Donoho, C.W. Jr., A.E. Mitchell, and M.J. Bukovac. 1961. The absorption and translocation of ring labeled $\mathrm{C}^{14}$ naphthaleneacetic acid in the apple and peach. Proc. Amer. Soc. Hort. Sci. 78:96-103.

Ebert. A. and F. Bangerth. 1981. Relations between the concentration of diffusable and extractable gibberellin-like substances and the alternate-bearing behavior in apple as affected by chemical fruit thinning. Scientia Hort. 15:45-52.

Ebert, A. and F. Bangerth. 1982. Possible hormonal modes of action of three apple thinning agents. Scientia Hort. 16:343-356.

Edgerton, L.J. 1973a. Chemical thinning of flowers and fruits, p. 435-474. In: 
T.T. Kozlowski (ed.). Shedding of plant parts. Academic Press, New York.

Edgerton, L.J. 1973b. Control of abscission of apples with emphasis on thinning and pre-harvest drop. Acta Hort. 34:333-343.

Greene, D.W., W.R. Autio, J.A. Erf, and Z.Y. Mao. 1992. Mode of action of benzyladenine when used as a chemical thinner on apples. J. Amer. Soc. Hort. Sci. 117:775-779.

Hartman, F.O. and F.S. Howlett. 1962. Effects of naphthaleneacetic acid on fruit setting and development in the apple. Ohio Agr. Expt. Sta. Res. Bul. 920.

Knight, J.N. 1983. Translocation properties of carbaryl in relation to its use as an apple fruitlet thinner. J. Hort. Sci. 53:371-379.

Luckwill, L.C. 1953. Studies of fruit development in relation to plant hormones. II. The effect of naphthalene acetic acid on fruit set and fruit development in apples. J. Hort. Sci. 28:25-40.

Luckwill, L.C. and C.P. Lloyd-Jones. 1962. The absorption, translocation and metabolism of 1-naphthaleneacetic acid applied to apple leaves. J. Hort. Sci. 37:190-206.

Marsh, H.V. Jr., F.W. Southwick, and W.D. Weeks. 1960. The influence of chemical thinners on fruit set and size, seed development, and pre-harvest drop of apples. Proc. Amer. Soc. Hort. Sci. 75:5-21

Murneek, A.E . 1954. The embryo and endosperm in relation to fruit development, with special reference to the apple, Malus Sylvestris. Proc. Amer. Soc. Hort Sci. 64:573-582.

Murneek, A.E. and F.G. Teubner. 1953. The dual action of naphthaleneacetic acid in thinning of apples. Proc. Amer. Soc. Hort. Sci. 61:149-154.

Rahemi, M. 1981. Role of ethylene and the effect of supplemental hand pollination in apple (Malus domestica Borkh.) fruit set. PhD Diss., Michigan State Univ., E. Lansing.

Schneider, G.W. 1973. Translocation of ${ }^{14} \mathrm{C}$-indoleacetic acid and sucrose in excised apple pedicels. J. Amer. Soc. Hort. Sci. 98:278-281.

Schneider, G.W. 1974. Ethylene evolution and apple fruit thinning. J. Amer. Soc. Hort Sci. 100:356-359.

Schneider, G.W. 1975. ${ }^{14} \mathrm{C}$-Sucrose translocation in apple J. Amer. Soc. Hort. Sci. 100:22-24.

Schneider, G.W. 1977. Studies on the mechanism of fruit abscission in apple and peach. J. Amer. Soc. Hort. Sci. 102:179-181.

Schneider, G.W. and A.M. Lasheen. 1973. NAA and Sevin on composition, development and abscission of apple fruit. HortScience 8:103-104.

Schumacher, R., R. Neuweiler, and W. Stadler. 1993. Einfluss der Fruchtausdunnung auf Fruchtansatz, Frucht-und Treibwachstum. Schweiz. Zeitschrift fur Obst- und Weinbau 129:421-426.

Southwick, R.W., W.D. Weeks, E. Sawada, and J.F. Anderson. 1962. The influence of chemical thinners and seeds on the growth rate of apples. Proc. Amer. Soc. Hort. Sci. 80:33-42.

Stopar, M., B.L. Black, and M.J. Bukovac. 1997. The effect of NAA and BA on carbon dioxide assimilation by shoot leaves of spur-type 'Delicious' and 'Empire' apple trees. J. Amer. Soc. Hort. Sci. 122:837-840.

Struckmeyer, B.E and R.H. Roberts. 1950. A possible explanation of how naphthalene acetic acid thins apples. Proc. Amer. Soc. Hort. Sci. 56:76-78.

Teubner, F.G. and A.E. Murneek. 1955. Embryo abortion as mechanism of "hormone" thinning of fruit. Missouri Agr. Expt. Sta. Bul. 590.

Tromp, J. and S.J. Wertheim. 1980. Synthetic growth regulators: Mode of action and application in fruit production, p. 137-150. In: Physiological aspects of crop productivity. Proc 15th Colloq. Intl. Potash Inst., Bern.

Walsh, C.S., H.J. Swartz, and L.J. Edgerton. 1979. Ethylene evolution in apple following post-bloom thinning sprays. HortScience 14:704-706.

Wertheim, S.J. 2000. Developments in the chemical thinning of apple and pear. Plant Growth Regulat. 31:85-100.

Williams, M.W. 1979. Chemical thinning of apples. Hort. Rev. 1:270-300.

Williams, M.W. 1981. Response of apple trees to aminoethoxyvinylglycine (AVG) with emphasis on apical dominance, fruit set, and mechanism of action of fruit thinning chemicals. Acta Hort. 120:137-141.

Williams, M.W. and L.P. Batjer. 1964. Site and mode of action of 1-naphthyl $\mathrm{N}$-methylcarbamate (Sevin) in thinning apples. Proc. Amer. Soc. Hort. Sci. 85:1-10.

Yuan, R. and D.W. Greene. 2000. Benzyladenine as a chemical fruit thinner for 'McIntosh' apples. I. Fruit thinning effects and associated relationships with photosynthesis, assimilate translocation, and nonstructural carbohydrates. J. Amer. Soc. Hort. Sci. 125:169-176.

\title{
Blossom Thinning of Pome and Stone Fruit
}

\author{
Esmaeil Fallahi ${ }^{1}$ \\ Department of Plant, Soil, and Entomological Sciences, Parma Research and Extension Center, \\ University of Idaho, 29603 U of I Lane, Parma ID 83660 \\ Kathleen M. Willemsen ${ }^{2}$ \\ Department of Horticulture and Landscape Architecture, P.O. Box 646414, \\ Washington State University, Pullman, WA 99164-6414
}

\begin{abstract}
Blossom thinners are caustic and reduce fruit set by damaging different flower parts, including anthers, stigma, style, and pollen tubes, and thus prevent fertilization. Hilderbrand (1944) studied the mode of action of the blossom thinner sodium dinitro-ortho-cresol (Elgetol, 19\% a.i.) and reported that Elgethol is a pollenicide. Early thinning of apples (Malus $\times$ domestica Borkh.) is important because of its impact on fruit size and next season flower bud initiation. In the past, apple cultivars were often sprayed with Elgethol during full bloom, followed by a post-bloom application of a fruit thinner such as 1-naphthyl N-methylcarbamate (carbaryl) with or without naphthalene acetic acid (NAA) (Williams and Edgerton, 1981). Carbaryl and NAA are effective post-bloom fruit thinners for a period of 4 to 5 weeks after full bloom (Byers et al., 1990; Byers and Carbaugh, 1991; Williams and Edgerton, 1981). Gibberellin $\mathrm{A}_{4+7}$ and 6-benzylamino purine (6-BAP) are also effective post-bloom fruit thinners for 'Delicious' apples (Byers and Carbaugh, 1991; Ferree, 1996; Greene, 1984; Greene and Lord, 1985). Elgetol was removed from the market in 1989 because of the high cost of re-registration. Elgetol's loss renewed research efforts to find blossom thinners with similar modes of action. Full-bloom
\end{abstract}

$\overline{\text { Received for publication } 13 \text { July 2000. Accepted for publication } 29 \text { Sept. } 2001 .}$ ${ }^{1}$ Professor, Tree Fruit Physiologist.

${ }^{2}$ Associate Professor, Tree Fruit Physiologist and Extension Horticulturist,Tree Fruit and Grape Production. sprays of sulfcarbamide (Wilthin, 79\% a.i.), pelargonic acid (Thinex), and endothallic acid (endothall), or petal fall applications of carbaryl (Sevin XLR Plus, 0.48 kg a.i./L; Aventis, Research Triangle Park, N.C.) were developed as replacements for Elgetol. These compounds were reported to result in satisfactory thinning and fruit set in 'Delicious' (Williams, 1993, 1994) and 'Rome' apples (Fallahi, 1997,1998; Fallahi et al., 1997).

Blossom thinning in stone fruits, particularly peaches [Prunus persica (L.) Batsch] and plums [(Prunus domestica (L.) and Prunus salicina (Lindl.)] is extremely important because of the high cost of hand thinning and lack of any post-bloom thinner. Since stages of blossom development are not as distinct as in pome fruit, it is difficult to chemically thin stone fruit blossoms. However, some blossom thinners were used to successfully thin peaches (Fallahi, 1998; Fallahi et al, 1997, 1998; Southwick et al., 1998).

\section{NEW BLOSSOM THINNERS}

Hydrogen cyanamide. Hydrogen cyanamide (Dormex, 50\% a.i.) and other chemicals were initially used to reduce chilling requirements of peaches grown in southwest Arizona (Fallahi et al., 1990). Hydrogen cyanamide applied at "pink bloom" reduced the number of open blossoms. Based on this observation, hydrogen cyanamide was sprayed at different concentrations at pre-bloom and full-bloom on 